\title{
A syntactic typology of topic, focus and contrast
}

Ad Neeleman, Elena Titov,

Hans van de Koot and Reiko Vermeulen (UCL)

\section{Introduction}

As is well-known, topics and foci have dedicated positions in a variety of languages. This paper is concerned with the question of what this fact can tell us about the typology of information-structural notions and their mapping to the syntax. We argue that the data support two conclusions, both of which can be shown to clash with a cartographic outlook on sentence structure (for a general overview of the cartographic framework, see Cinque 2002, Rizzi 2003, and Belletti 2004). The first is that there are no fixed landing sites for topic and focus movement. The second is that there are cross-cutting generalizations over topics, over foci, and over contrastive elements. These jointly motivate the following four-way typology:

\begin{tabular}{|l|c|c|}
\cline { 2 - 3 } \multicolumn{1}{c|}{} & Topic & Focus \\
\hline Non-contrastive & $\begin{array}{c}\text { aboutness topic } \\
\text { [topic] }\end{array}$ & $\begin{array}{c}\text { new information focus } \\
\text { [focus] }\end{array}$ \\
\hline Contrastive & $\begin{array}{c}\text { contrastive topic } \\
\text { [topic, contrast] }\end{array}$ & $\begin{array}{c}\text { contrastive focus } \\
\text { [focus, contrast] }\end{array}$ \\
\hline
\end{tabular}

What the table in (1) expresses is that topic and focus are basic notions in information structure that can be enriched to yield a contrastive interpretation. In other words, a contrastive topic and a contrastive focus are an aboutness topic and a new information focus interpreted contrastively. We are not the first to make a suggestion along these lines; related ideas can be found in Vallduví and Vilkuna 1998, Molnár 2002, McCoy 2003, and Giusti 2006.

Cartography is based on two core tenets. First, it assumes a one-to-one correspondence between syntactic position and interpretive effect. Topic and focus will hence be realized in designated functional projections, which according to Rizzi (1997) are located in the left periphery of the clause. Second, cartography tacitly adopts a radically decompositional approach to syntactic categories. This second assumption is in fact implied by the first:

* This paper is part of the output of the AHRC-funded project 'A Flexible Theory of Topic and Focus Movement' (Grant nr. 119403). 
if there are two interpretive effects, there must be two designated positions in which these licensed. Consequently, every semantic feature that has syntactic import must head its own functional projection. This drives the cartographic research program to the highly articulated phrase structure found in much recent work.

Our claim that topic and focus do not have designated positions in the clause obviously runs counter to the first tenet of cartography. The crosscutting generalizations that we establish have the consequence that the presence of [contrast] is conditional upon the presence of either [topic] or [focus]. This conclusion does not mesh with the second tenet of cartography, that of radical syntactic decomposition. We will develop both arguments in more detail as we proceed.

In order to make the comparison with cartography as explicit as possible, we will treat [topic], [focus] and [contrast] as privative syntactic features. This is a matter of presentational convenience; in fact, none of our arguments are adversely affected if [topic], [focus] and [contrast] are merely discourse notions targeted by mapping rules operating between syntax and information structure.

The strongest evidence for the typology in (1) comes from the syntactic distribution of constituents with different information-structural functions. If we treat contrast, topic and focus as privative features, we expect to find rules that mention [topic] and therefore generalize over aboutness topics and contrastive topics, rules that mention [focus] and therefore generalize over new information focus and contrastive focus, and rules that mention [contrast] and therefore generalize over contrastive topic and contrastive focus. We do not expect to find rules that generalize over aboutness topics and new information foci, over contrastive topics and new information foci, or over aboutness topics and contrastive foci. None of these pairs share a feature.

The import of these predictions of course depends on what we mean by notions like 'focus', 'topic' and 'contrast'. We take 'focus' to be the information highlighted in a proposition. For example, in the answer to a WH-question, the constituent that corresponds to the WH-expression is a focus. The rest of the sentence functions as the background to this focus; that is, the focus is highlighted with respect to this material (throughout we use small capitals to mark foci):

(2) a. What did Rutger buy?

b. Rutger bought A GUN. 
We follow Reinhart (1981) in assuming that topics should be defined in terms of aboutness (the linguistic relevance of aboutness is motivated by several phenomena, including anaphora resolution). On Reinhart's definition, a topic is the entity that the utterance is about. Thus, while 'focus' is notion operative at the level of propositions, 'topic' is primarily a discourse notion (see Tomioka 2007b for recent discussion). But of course some syntactic constituents are used to manipulate the topic of discourse (by introducing a new topic, narrowing down or broadening the current topic, and so on). These are often referred to as sentence topics or linguistic topics. We reserve the feature [topic] to distinguish them from constituents with other information-structural functions.

Linguistic topics should be distinguished from expressions contained in the utterance that merely index the current topic of discourse (see Lambrecht 1994 for extensive discussion) ${ }^{1}$. We can illustrate the distinction using the following discourse (throughout we use double underlining to mark topics):

(3) a. Maxine was introduced to the queen on her birthday.

b. She was wearing a special dress for the occasion.

In (3a), Maxine is a linguistic topic: it introduces a new topic of discourse. The initial comment made about Maxine is that she was introduced to the queen on her birthday. The pronoun her in this comment is not a linguistic topic, but a category that indexes the topic. We take the same to be true of the continuation of the discourse in (3b), which is what one might call an 'all-comment' sentence, linked to the topic Maxine through the pronoun she (see Vallduví 1992, Lambrecht 1994, and Vallduví and Engdahl 1996 for discussion). ${ }^{2}$ A consequence of this view is that the traditional aboutness test for topics is not a reliable indicator of linguistic topics (i.e. constituents that bear the [topic] feature). Rather, it identifies the current topic of discourse. In what follows, we will introduce tests for linguistic topichood where appropriate.

The final notion we rely on is that of contrast. Constituents that are contrastive are understood to belong to a contextually given set out of which they are selected to the exclusion of at least some other members of the set. Both topics and foci can be interpreted contrastively. In English,

\footnotetext{
1 Our notion of (linguistic) topic corresponds to what Lambrecht calls 'reference-oriented topic expressions', while our notion of indexing elements corresponds to his 'role-oriented topic expressions'.

2 Backgrounds differ from comments in this respect: as focus is a notion associated with propositions, there is no such thing as an all-background sentence.
} 
contrastive topics and foci are marked by a special intonation. Contrastive foci typically carry what Jackendoff 1972 calls an A-accent: a plain high tone $\left(\mathrm{H}^{*}\right)$, often followed by a default low tone (see Büring 2003 and references mentioned there). Contrastive topics carry a B-accent, maximally realized as $\mathrm{L}+\mathrm{H}^{*}$ followed by a default low tone and a high boundary tone $(\mathrm{L} \mathrm{H} \%)$. We will not indicate A- and B-accents in examples, but all constituents marked as contrastive topic or focus are taken to carry these accents in languages that distinguish them (like Dutch). Further tests that identify contrastive topics and contrastive foci will be introduced as we proceed. (Throughout we use italics to mark contrast.)

(4) a. Rutger bought $A G U N$.

b. Maxine was introduced to the queen on her birthday.

On the appropriate intonational contours, (4a) conveys that Rutger bought a gun and not certain other relevant items, while (4b) highlights that the speaker knows that Maxine was introduced to the queen on her birthday, but could not make the same statement about other relevant individuals. (This could be because the speaker lacks knowledge about these other individuals or because he or she knows that a similar statement about them would not be true.)

On these definitions of topic, focus and contrast, the kind of rules excluded by the table in (1) are indeed not attested. However, the kind of generalizations permitted by the table are indeed attested. In each of the following sections we discuss a language with a data pattern that can be captured by a rule that refers to topic], [focus] or [contrast]. In section 2, we show Dutch A'-scrambling targets constituents with a contrastive interpretation. In section 4, we show that in Japanese both aboutness topics and contrastive topics must appear in the left periphery of the clause, a requirement that sets them apart from other constituents. In section 5, we show that in Russian new information foci and contrastive foci have the same underlying position. The presence or absence of contrastiveness, however, gives rise to very different surface syntax, as contrastive foci are fronted. (The case against cartography is spelled out in more detail in sections 3 and 6.)

There is a one generalization whose effects can be found in all three languages:

(5) [Contrast] licenses A'-movement. 
It is obvious that (5) holds in Dutch. In Japanese, contrastive topics can be shown to be associated with an $\mathrm{A}^{\prime}$-trace, while aboutness topics are associated with a null resumptive pronoun (see section 4). In Russian, contrastive foci undergo A'-fronting, while new information foci remain in clause-final position (see section 5).

The generalization in (5) is of course not new. It goes back to at least Kiss 1998, where evidence for it is provided from languages other the ones discussed here. An obvious question is why the generalization should hold. Kiss suggests that contrast is inherently quantificational and licenses A'movement, because this operation in general is used to create structures of quantification (a similar idea can be found in Rizzi 1997). Although this suggestion faces a number of serious complications, we find it attractive. However, for reasons of space, we cannot develop it in any detail here and must leave (5) as a descriptive generalization.

\section{Dutch A'-scrambling ${ }^{3}$}

There is general agreement that, in Germanic and beyond, there are two types of scrambling. A-scrambling feeds and bleeds binding and secondary predication, does not give rise to weak crossover effects, is clause-bounded, and does not give rise to scope-reconstruction. We cannot illustrate all these properties here, but for relevant discussion, see Vanden Wyngaerd 1989, Mahajan 1990, Zwart 1993, Neeleman 1994, and Neeleman and Van de Koot 2007. In contrast, A'-scrambling does not affect binding or secondary predication, gives rise to weak crossover effects, is not clausebounded, and reconstructs (obligatorily) for scope. Again, we will not demonstrate these properties here, but refer the reader to Neeleman 1994, Jacobs 1997, Haider and Rosengren 1998, and Neeleman and Van de Koot 2007 for discussion.

In Dutch, the language we will concentrate on in this section, the two types of scrambling can be easily told apart, because only A'-scrambling can alter the basic order of arguments (subject - indirect object - direct object). ${ }^{4}$ A-scrambling is restricted to the reordering of arguments and adjuncts (see Zwart 1993, and references cited there). ${ }^{5}$ The two types of scrambling are also associated with different interpretive effects. Ascrambling operations typically mark the scrambled DP as discourse-

\footnotetext{
${ }^{3}$ This section is partly based on Neeleman and Van de Koot 2008.

${ }^{4}$ Note that A'-scrambling can also affect categories other than DPs, including adverbials.

5 Some speakers of Dutch marginally allow A-scrambling of a direct object across an indirect object, a possibility more generally available in German. The judgments reported here are from speakers who reject such scrambling.
} 
anaphoric; see Reinhart 1995, Neeleman and Reinhart 1998, and Choi 1999, among others, for discussion. A'-fronting operations typically require the moved DP to be interpreted as either a contrastive focus or a contrastive topic (see Neeleman 1994 and Frey 2001):

(6) a. Ik geloof dat [alleen DIT boek] Jan Marie $t$ gegeven heeft. I believe that only this book John Mary given has 'I believe that John has given only this book to Mary.'

b. Ik geloof dat [zo'n boek] alleen JAN Marie $t$ gegeven heeft. I believe that such-a book only John Mary given has 'I believe that only John has given such a book to Mary.'

(7) a. Ik geloof dat Jan [alleen DIT boek] Marie $t$ gegeven heeft. I believe that Johnonly this book Mary given has 'I believe that John has given Mary only this book'

b. Ik geloof dat Jan [ zo'n boek] alleen MARIE tgegeven heeft. I believe that John such-a book only Mary given has 'I believe that John has given such a book only to Mary.'

(8) a. [Alleen DIT boek] zou Jan Marie $t$ geven. only this book would John Mary give 'John would give Mary only this book.'

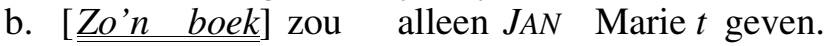
such-a book would only John Mary give 'Only John would give Mary such a book.'

The data demonstrate that $\mathrm{A}^{\prime}$-scrambling can target a variety of positions. Irrespective of whether the moving phrase is a topic or a focus, it can land in a position between the complementizer and the subject, as in (6), in a position between the subject and the indirect object, as in (7), or in the first position in main clauses, as in (8). Further landing sites are available in structures containing adverbs, as these are (usually) freely ordered with respect to moved topics and foci.

DPs that are not interpreted contrastively cannot be scrambled across arguments, even if they are topic or focus.

One might conjecture that $\mathrm{A}^{\prime}$-scrambling is licensed by a mapping rule that assigns a moved constituent an interpretation as contrastive. The drawback of this suggestion is that constituents that remain in situ can also be interpreted in this way, so that it is difficult to see what effect the movement could have on the displaced category. This being so, we explore 
the possibility that $\mathrm{A}^{\prime}$-scrambling does not affect the interpretation of the moved category itself, but rather that of the constituent to which it adjoins.

The idea, then, is that movement of a contrastive topic or focus marks that material in the sentence used to calculate the contrast (the statement made about the contrasted category to the exclusion of alternatives). We will call this material the domain of contrast (DoC). Thus, if a contrastive topic or focus remains in situ, the domain of contrast need not be a constituent, as indicated in (9a). Therefore, in interpreting the sentence, the hearer must construe an appropriate domain of contrast based on contextual clues. This is different if the contrastive constituent in (9a) moves out of YP, so that an otherwise discontinuous domain of contrast is turned into a constituent, as shown in (9b).

(9) a.

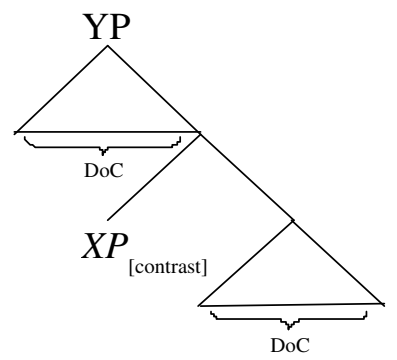

b.

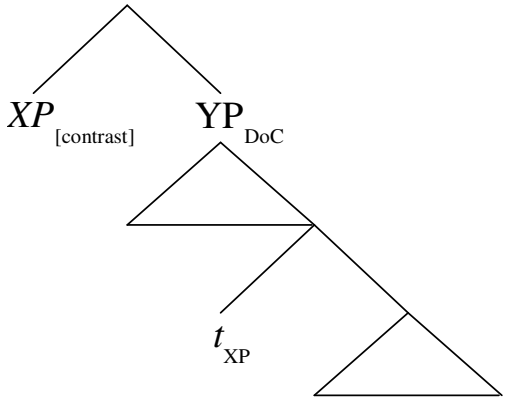

In sum, movements of contrastive topics and foci do not mark the discourse functions of these elements themselves, but rather their domain of contrast; that is, the material relevant to calculating the set of alternatives on which the contrast operates (see Wagner 2005 for related ideas). This proposal can be implemented through the mapping rule in (10). (The structure in (11), to which (10) refers, contains the diacritic $\mathcal{M}$ that we have used in previous work to encode A'-movement, on a par with the slash notation in HPSG. ${ }^{6}$

DoC Marking

If XP in (11) is interpreted contrastively, then interpret $\mathrm{N}_{2}$ as the domain of contrast.

${ }^{6}$ The proposal outlined here constitutes a correction on Neeleman and Van de Koot 2008, where it is assumed that A'-scrambling marks a comment or a background rather than a domain of contrast. 
$(11)$

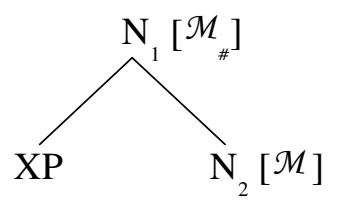

The proposal summarized in (10) and (11) entails that the examples in (6) and (7) differ as to whether or not the embedded subject is included in the domain of contrast.

An immediate question that this proposal raises is how domains of contrast can apparently be of different semantic types (a proposition with a single $\lambda$-bound variable in (6) and a constituent with a $\lambda$-bound variable and an open slot for the subject in (7)). We assume, following Schwarzschild 1999 and others, that a contrast is always based on an expression containing a single $\lambda$-bound variable. This expression is used in information structure to generate the set of alternatives from which the contrastive constituent is chosen. If so, there must be an information-structural procedure of existential closure that transforms the domain of contrast in (7) into an expression of the right type. The interpretation of the existentially bound variable is then provided by the context (it must be as specific as the context allows). Thus, the contrast in (6a) is based on the expression $\lambda x$ [John has given Mary $x$ ], while the contrast in (7a) is based on $\lambda x \exists y$ [ $y$ has given Mary $x]$. If $y$ is interpreted as 'people', then (6a) and (7a) differ in the set of alternatives from which the contrastive focus is selected, namely the set of things that John would give Mary versus the set of things that people would give Mary.

The proposal put forward above makes a number of predictions. The first set of predictions has to do with the interaction between DoC marking and well-formedness constraints on information structure. It is usually assumed that the first partitioning of a sentence at information structure distinguishes a topic and a comment. The comment may then be further partitioned into a focus and a background. This order of partitioning is in line with the suggestion that the topic-comment partitioning applies to an utterance, while the focus-background partitioning applies to a proposition. Consequently it is possible to embed a focus in a comment (as in (12a)), but it is not possible to embed a topic in a background (as in (12b). (For relevant discussion, see Prince 1981, Reinhart 1981, 1995, 2006, Vallduví 1992, Lambrecht 1994, and Hajičová et al. 1998.)

(12) a. topic [COMment FOCUS [ [вACKGRound $\cdots$ ] ]

b. *FOCUS [Background topic [Comment $\cdots$ ] ] 
Given that these partitioning are exhaustive, the domain of contrast for a focus must consist of material chosen from the background, while the domain of contrast for a topic must consist of material chosen from the comment. This implies that DoC marking does not only identify material on which a contrast is based, but also forces this material to be construed as belonging to the background or the comment, depending on the interpretation of the contrastive constituent.

We should emphasize that $(12 a, b)$ are information structures, and not syntactic configurations. Given that the mapping between syntax and information structure need not be isomorphic, the ban on the embedding of a topic-comment structure in a background will not directly restrict syntactic structure. For instance, it does not follow from (12b) that topics cannot be preceded by foci. Any impact of information-structural constraints on word order in Dutch must result from the application of DoC marking. If no movement takes place, no material is marked as belonging to a background or a comment, and hence the syntax does not impose any restrictions on the mapping to information structure. However, we expect that the effects of (12b) will be felt if focus movement takes place. The material contained in the domain of contrast marked by movement of a focus must be part of its background. Since by (12b) a background cannot contain a topic, it is predicted that focus movement out of a constituent containing a topic will be impossible.

In other words, what we expect is that the placement of in situ topics and foci is free. However, while a topic can move out of a constituent containing a focus (whether in situ or not), a focus cannot move out of a constituent containing a topic (whether in situ or not).

In order to demonstrate that these predictions are borne out, we must sharpen our criteria for classifying a constituent as topic or focus. As pointed out earlier, contrastive foci are associated with an A-accent and contrastive topics with a B-accent. In addition, there are contextual criteria. It is well known that in the answer to a WH-question, the constituent that corresponds to the $\mathrm{WH}$-operator is (usually) a focus. If it is interpreted contrastively, it qualifies as a contrastive focus. By this criterion, de bonen 'the beans' in $(13 a, b)$ is a contrastive focus. As we have already seen, a context that favours an interpretation of a constituent as contrastive topic is one in which the hearer answers a question that differs in that constituent from the one being asked. This allows us to classify Wim in $(13 \mathrm{a}, \mathrm{b})$ as a contrastive topic (the original question mentioning Fred). ${ }^{7}$

${ }^{7}$ The judgments given here and below are based on a pronunciation of the examples in which the constituent marked as focus carries a plain high tone, and the constituent marked as topic carries a tune consisting of a high tone, a low tone 
What the data in (13) show, then, is that an in-situ focus may follow a topic, but cannot move across it. ${ }^{8,9}$

(13) Hoe zit het met FRED? Wat heeft HIJ gegeten?

'What about Fred? What did he eat?'

Nou, dat weet ik niet, maar ik geloof

'Well, I don't know, but I believe'

and a high boundary tone (this intonation of Dutch topics is in line with the observations reported in Van Hoof 2003). As far as we can judge these matters, this pronunciation is very similar to what is found in English.

${ }^{8}$ As was pointed out to us by Michael Wagner (p.c.), the context in (13) and comparable ones below do not force the interpretations indicated, but merely favour them. All the contexts we use are based on implicit multiple WH-questions. In (13), this question is Who ate what?, while in (16) below, it is What was eaten by whom? Answers to multiple WH-questions tend to be constructed in such a way as to line up the topic with the fronted WH-phrase and the focus with the in situ WH-phrase. Thus, Who ate what? is most commonly answered by something like John ate the BEANS, Mary ate the CHEESE, etc. However, when there is reason to do so, it is also possible to swap the topic and focus functions, yielding answers like JOHN ate the beans, MARY ate the cheese, etc. (see Roberts 1996 and Büring 2003). Given that the contexts we use presuppose implicit multiple WH-questions, the possibility of a topic-focus swap also presents itself. Hence, in evaluating our empirical claims, one should not just rely on the effects of context, but also consider other indicators of topic- and focushood.

${ }^{9}$ Notice that overt topic movement cannot be used to rescue structures in which a topic is contained in the background of a moved focus. We speculate that this is because "repair by movement" would violate Relativized Minimality: focus movement creates an A'-position that blocks association of the topic with its trace. If so, comparable structures in which a topic is linked to a pronoun should be acceptable. Indeed, there is a sharp contrast between (i) and (ii). Moreover, topic fronting across a moved focus is widely attested in languages that have clitic doubling (such as Italian) or allow radical pro drop (such as Japanese).

(i) * Marie heeft DIT boek Jan $t$ zeker $t$ niet gegeven. Mary has this book John certainly not given.

(ii) Wat Marie betreft, DIT boek heeft Jan haar zeker $t$ niet gegeven. What Mary regards, this book has John her certainly not given. 'As for Mary, John has certainly not given her this book.'

For related discussion, see Rochemont 1989, Culicover 1991, Browning 1996, among others. 
a. dat Wim van de BONEN meer gegeten heeft dan vorig jaar. that Bill from the beans more eaten has than last year 'that Bill has eaten more from the beans than last year.'

b.\#dat [van de BONEN] $\underline{\underline{\text { Wim }} t}$ meer gegeten heeft dan vorig jaar. that from the beans Bill more eaten has thanlast year

There is a further test that can be used to corroborate the classification of topics and foci: negative quantifiers can function as foci, but not as topics (for obvious semantic reasons). This is corroborated by the fact that they cannot appear in the English as for construction, which marks topics:

\section{\#As for no boy, I like him.}

Therefore, if in the relevant context a constituent can be replaced by a negative quantifier, it cannot be a topic. Indeed, when Wim in (13a) is replaced by niemand 'nobody', the result is decidedly odd, as shown in (15a). ${ }^{10}$ (The hearer is left to wonder which person is referred to as 'nobody'.) However, the variant of (13b) in (15b), in which de bonen 'the beans' has been replaced by nergens 'nothing', is perfectly natural.

(15) a.\#dat niemand van de BONENmeer gegeten heeft dan vorig jaar. that nobody from the beans more eaten has than last year 'that nobody has eaten more from the beans than last year.'

b. dat Wim NERGENS van meer gegeten heeft dan vorig jaar that Bill nothing of more eaten has than last year 'that Bill has not eaten more from anything than last year.'

The data in (16) show that, by contrast, an in-situ topic may follow an insitu focus or move across it. This observation is corroborated by the fact that in neither (16a) nor (16b) 'the beans' can be replaced by a negative quantifier (see (17)), whereas replacing 'Bill' by 'nobody' is unproblematic in both of these examples (see (18)). The results of this test are consistent with a classification of 'the beans' as topic and of 'Bill' as focus.

(16) Hoe zit het met de SOEP? Wie heeft DIE gegeten?

'What about the soup? Who ate that?'

Nou, dat weet ik niet, maar ik geloof ...

'Well, I don't know, but I believe ...'

\footnotetext{
${ }^{10}$ The answer in (17a) is felicitous if the B-accent on the subject is omitted. Doing so allows the example to be construed as providing indirect information about Fred, namely that he did not eat more from the beans than he did last year.
} 
a. dat WIM van de bonen meer gegeten heeft dan vorig jaar. that Bill from the beans more eaten has than last year

b. dat [ van de bonen] WIM $t$ meer gegeten heeft dan vorig jaar. that from the beans Bill more eaten has than last year 'that Bill has eaten more from the beans than last year.'

(17) a.\#dat WIM nergens van meer gegeten heeft dan vorig jaar. that Bill nothing of more eaten has than last year

b.\#dat [ nergens van] WIM $t$ meer gegeten heeft dan vorig jaar. that nothing of Bill more eaten has than last year 'that Bill has not eaten more from anything than last year.'

(18) a. dat NIEMAND van de bonen meer gegeten heeft dan vorig that nobody from the beans more eaten has than last jaar. year

b. dat [ van de bonen] NIEMAND $t$ meer gegeten heeft dan vorig that from the beans nobody more eaten has than last jaar. year

'that nobody has eaten more from the beans than last year.'

The data considered so far could be captured by a linear constraint. However, as pointed out by an anonymous reviewer, the proposal based on the mapping rule in (10) makes a stronger prediction, namely that focus movement out of a constituent containing a topic will give rise to ungrammaticality whether the launching site of the relevant movement precedes or follows the topic. As we will now show, this stronger prediction is correct.

The answers in (19) involve a ditransitive verb. The context is set up in such a way as to favour a reading of the indirect object as focus (it answers the WH-question), and the direct object as topic (it switches the topic of the discourse from the antique sideboard to the clock). While the answer in (19a) is felicitous, the answer in (19b), where the focus has moved, cannot be produced with the intonation indicated.

(19) Hoe zit het met het dressoir? Wie heeft grootvader dat nagelaten?

'How about the sideboard? To whom has granddad bequeathed that?'

Nou, dat weet ik niet, maar ik geloof

'Well, I don't know, but I believe ...'

a. dat grootpapa zijn buren de klok heeft willen nalaten. 
that granddad his neighbours the clock has want bequeath

b. \#dat zijn buren grootpapa $t$ de klok heeft willen nalaten.

that his neighboursgranddad the klok has want bequeath 'that granddad wanted to bequeath the clock to his neighbours.'

As expected, it is possible to move a topic from a position preceding a focus, as shown in (20). Our classification of 'neighbours' as topic and 'clock' as focus in the examples in (20) receives support from the negativequantifier test introduced above, but for reasons of space we will not demonstrate this here.

(20) Hoe zit het met tante Jo? Wat heeft grootpapa haar nagelaten?

'How about auntie Jo? What has granddad bequeathed to her?'

Nou, dat weet ik niet, maar ik geloof

'Well, I don't know, but I believe ...'

a. dat grootpapa zijn buren de klok heeft willen nalaten. that granddad his neighbours the clock has want bequeath

b. dat [DP zijn buren] grootpapa $t_{\mathrm{DP}}$ de klok heeft willen that his neighbours granddad the clock has want nalaten.

bequeath

'that granddad wanted to bequeath the clock to his neighbours.'

Our proposal makes a final prediction concerning the distribution of contrastive topics and contrastive foci. This prediction is not about what can not be contained in the domain of contrast, but rather about what must be contained in it. In particular, it can be shown to follow from our assumptions that a contrastive topic cannot move to a position below a contrastive focus. Consider the following data:

(21) Hoe zit het met de nietmachine? Wie heeft Jan daarom gevraagd?

'What about the stapler? Who has asked John for that?'

Nou, dat weet ik niet, maar...

'Well, I don't know, but...'

a. ik geloof dat PIET Jan om de liniaal heeft willen vragen. I believe that Peter John for the ruler has want ask

b. \#ik geloof dat PIET [ ${ }_{\mathrm{PP}} \mathrm{Om}$ de liniaal] Jan $t_{\mathrm{PP}}$ heeft willen vragen.

I believe that Peter for the ruler John has want ask

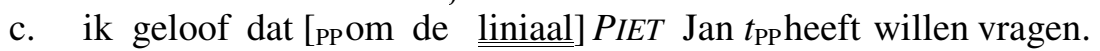

I believe that for the ruler Peter John has want ask

'I believe that Peter has wanted to ask John for the ruler.' 
The leading sentence in (13) sets up a context in which we are discussing the various things that his fellow workers have asked John for. In all three answers there is a shift in topic from the stapler to the ruler, identifying the latter as a contrastive topic. The set of elements out which this contrastive topic is selected are those things that Peter - as opposed to other people might have asked John for (this is because Peter is a contrastive focus). (21a) is a felicitous answer because nothing moves, and hence the domain of contrast for both topic and focus can be construed freely so as to fit the context. The short topic movement in (21b) marks a domain of contrast that contains two open positions and that therefore must undergo existential closure, yielding $\lambda x \exists y$ [y has wanted to ask John for $x]$ (see the beginning of this section for details). Since the interpretation of $y$ must be based on the immediate context, we are forced to interpret the existentially bound variable as 'his fellow workers'. In other words, the contrast is based on the set of office equipment that his fellow workers have wanted to ask John for, but it should be the set of office equipment that Peter has wanted to ask John for. Hence the degraded status of the answer in (21b). The answer in (21c) is fully grammatical because Peter is included in the domain of contrast and hence the contrastive topic is correctly selected out of the set of office equipment that Peter has wanted to ask John for.

As expected, in a context in which the indirect object John is interpreted as contrastive focus, short movement of the topic is felicitous:

(22) Hoe zit het met de nietmachine? Wie heeft Piet daarom gevraagd?

'What about the stapler? Who has Pete asked for that?'

Nou, dat weet ik niet, maar...

'Well, I don't know, but...'

a. ik geloof dat Piet JAN om de liniaal heeft willen vragen.

I believe that Peter John for the ruler has want ask

b. ik geloof dat Piet [PP om de liniaal] $J A N t_{\mathrm{PP}}$ heeft willen vragen.

I believe that Peter for the ruler John has want ask

'I believe that Peter has wanted to ask John for the ruler.'

Let us summarize the results of this section. We have argued that A'scrambling in Dutch is associated with the notion contrast. In particular, this type of movement marks the material relevant to calculating the set of alternatives on which the contrast operates. As a consequence, not all topics and foci can undergo A'-movement, but only those that are interpreted contrastively. Despite the fact that topic and focus movement have an identical trigger, they behave differently in certain respects. This is because 
the domain of contrast of a focus is taken from its background, while the domain of contrast of a topic is taken from its comment. As a consequence of the interaction between DoC marking and the information-structural constraints in (12), movement of a topic out of a constituent containing a focus is acceptable, but not the other way around. ${ }^{11}$

\section{Interim conclusion}

As explained in the introduction, cartography aims at a one-to-one relation between syntactic position and interpretive effect. For example, the interpretive functions combined in the C-node of Government and Binding Theory are distributed across several heads, which encode such things as subordination and sentence type. As a result of this kind of decomposition, a clause consists of a large number of functional projections generated in a fixed order. These should presumably include projections hosting topics and foci, as in Rizzi 1997.

On this view of syntax, one would at first sight expect universal ordering restrictions between any two constituents with distinct syntactic functions. Of course, reality is more complex and the way this additional complexity is dealt with in cartography is by allowing languages to vary in the extent to which movement takes place in overt or covert syntax. However, it can be demonstrated that this is insufficient to deal with the distribution of topics and foci in Dutch.

In other empirical domains that display word order variation, it has already been shown that an analysis in terms of a single hierarchy of functional projections is untenable, even under an extensive

\footnotetext{
${ }^{11} \mathrm{We}$ assume throughout that in situ focus does not move at LF. The data can also be captured, however, if in situ foci do move, so as to create a representation in which focus and background are constituents (abstracting away from many details; see Krifka 2006). Such an analysis requires two additional assumptions. To begin with, when overt focus movement takes place, LF-movement of material marked as belonging to a background must not be allowed. Such movement would repair the ill-formed example in (13b). By contrast, when no overt focus movement takes place, LF-movement must be generally available. For instance, the topic in (13a) must move, as it would otherwise be part of a background created by LF focus movement. (Note, however, that parallel structures created by overt movement give rise to ungrammaticality; see footnote 9 for discussion.)

The restriction that marking relations established in overt syntax cannot be undone at LF has a precedent in the literature on multiple WH-questions: if overt movement is used to mark the scope of a WH-operator, its scope cannot be extended through subsequent LF-procedures. Consequently, Who wonders what John bought? cannot be interpreted as a multiple WH-question, whereas Who said that John bought what? does allow such a reading (see van Riemsdijk 1978).
} 
parameterization of movement operations. For example, in reaction to Cinque 1999, a number of authors have pointed to problems with the order of adverbials (see Bobaljik 1999, Haider 2000, Ernst 2001, and Nilsen 2003). Bobaljik observes that arguments, verbs and auxiliaries in Italian can be freely interspersed in Cinque's (1999) adverbial sequence. This fact is incompatible with Cinque's proposal that the adverbial sequence is given by the order of functional projections in the verbal domain. Mutatis mutandis, the same conclusion holds of the variable placement of topics and foci in Dutch (see section 6 for further details).

Bobaljik argues that this hierarchy paradox may yet yield to a phrasestructural account. He suggests that there are independent argumental and adverbial hierarchies, which can be conceived of as separate tiers of the syntactic representation that are ultimately collapsed into a single structure. Bobaljik draws an analogy with the shuffling together of two decks of cards, a process that preserves the internal order of each deck while it intersperses the cards of one deck among those of the other.

Although Bobaljik's proposal provides an account of the Italian data in terms of what one might call 'relativized cartography', it cannot capture the syntax of topic and focus movement in Dutch. One could imagine that there is a topic-focus hierarchy (TopP $>$ FocP), whose positions can be freely interspersed with positions in Bobaljik's argumental hierarchy (AgrSP > AgrIOP > AgrOP). However, this is not sufficient to explain the fact that the order of constituents interpreted as topic and focus is free when they remain in situ, but rigid as soon as one of them moves. As we have shown, a topic can move out of a constituent containing an in situ focus, but a focus cannot move out of a constituent containing an in situ topic. The problem this raises for a 'relativized cartography' approach is that moved topics and moved foci would occupy a position in the topic-focus hierarchy, while topics and foci that remain in situ would occupy positions in the argumental hierarchy. Hence, ordering restrictions must be formulated that involve positions in more than one hierarchy, showing that a tier-based account is insufficient.

\section{Japanese topic fronting ${ }^{12}$}

In this section we discuss an example of a rule that mentions the feature [topic] and hence generalizes over aboutness topics and contrastive topics. The rule in question is part of Japanese grammar and requires topics to occur in clause-initial position:

(23) [Topic] is licensed in clause-initial position.

\footnotetext{
${ }^{12}$ This section is based on Vermeulen 2008.
} 
It may be surprising to some readers that the rule in question regulates word order rather than the distribution of the particle $w a$, which is often taken to be a topic marker. We will show, however, that there is only a oneway implication between topichood and $w a$-marking: topics are marked by $w a$, but constituents marked by wa need not be topics. We will show that non-clause-initial wa-phrases systematically fail to meet tests for topichood.

This proposal differs substantially from what one might consider the standard analysis of Japanese topics. It was suggested early on by Kuno (1973) that there are two uses of wa: thematic and contrastive. Phrases marked with thematic wa typically appear in clause-initial position and are interpreted as what the rest of the sentence is about. Phrases marked with contrastive wa implicate contrast and may remain in-situ. Although this goes some way towards the proposal we defend here, thematic and contrastive wa-phrases are generally analyzed as aboutness topics and contrastive topics, respectively (see Heycock 2007 for an overview of the literature). (Some of) the latter, then, would be topics in non-clause-initial position, contra (23).

We will now provide some arguments for (23), based on wellestablished tests for topichood. To begin with, it was argued by Reinhart (1981) that in the reply to a request such as tell me about $X, \mathrm{X}$ must be interpreted as an aboutness topic:

(24) a. Tell me about John.

b. Well, John is a PhD student enrolled at the University of Lund.

As an aside, we may note that there is something puzzling about this test. We have argued in the introduction that constituents that refer back to the current topic of discourse do not need to be linguistic topics themselves. Given that John seems to be introduced as the topic of discourse in (24a), why can't John in (24b) simply be a discourse-anaphoric expression? The solution to this puzzle lies in the fact that any given discourse comes in chunks (units of discourse), and for each of these a topic must be established. The imperative in (24a) is an instruction to start a new unit of discourse, and hence the constituent used to fix the topic of discourse for this unit, John in (24b), must itself be a linguistic topic.

When we apply Reinhart's test to Japanese, it turns out that the item X in the response must be marked with $w a$ and must appear in clause-initial position, as predicted by (23). The examples in (25) illustrate the point for 
subjects; those in (26) do so for objects. ${ }^{13}$ (We will discuss the nature of the empty category in (26a) below.)

(25) Tell me about that dog.

a. Sono inu-wa kinoo John-o kande-simatta.

that dog-WA yesterday John-ACC bite-closed

b. \#John $\mathrm{J}_{\mathrm{i}} \mathrm{O}$ sono inu-wa kinoo $t_{\mathrm{i}}$ kande-simatta.

John-ACC that dog-WA yesterday bite-closed

'The dog bit John yesterday.'

(26) Tell me about that hat.

a. Sono boosi $i_{-w a}$ John-ga kinoo $e_{\mathrm{i}}$ kaimasita.

that hat-WA John-NOM yesterday bought

b.\#John-ga sono boosi-wa kinoo kaimasita.

John-NOM that hat-WA yesterday bought

'John bought that hat.'

Contrastive topics display comparable behavior. As explained in section 3, one function of a contrastive topic is to shift the current topic of discourse from one item to another. Therefore, the exchange in (27) forces Bill-wa in the answer to be a contrastive topic, as this constituent is used to shift the topic from John. As predicted by (23), Bill-wa must appear in clause-initial position. (It differs from the simple aboutness topics in (25) and (26) in that it must bear stress.) The same observation holds when the constituent interpreted as contrastive topic is the object, as demonstrated by the examples in (28). ${ }^{14}$

(27) What did John eat at the party yesterday?

Hmm, John-wa doo-ka sira-nai-kedo,

'Well, I don't know about John, but...'

a. Bill-wa 8-zi-goro MAME-O tabeteita (yo)

Bill-WA 8 o'clock-around beans-ACC eating (PRT)

b.\#MAME $i_{i}-O \quad$ Bill-wa 8 -zi-goro $t_{\mathrm{i}}$ tabeteita (yo)

beans-ACC Bill-WA $8 o^{\prime}$ 'clock-around eating (PRT)

'As for Bill, he was eating beans around 8 o'clock.'

${ }^{13}$ For reasons unknown to us, an object wa-phrase prefers not to surface adjacent to a verb. In order to circumvent this issue, adverbials are inserted between object and verb throughout this section.

${ }^{14}$ If movement of contrastive foci in Japanese marks a domain of contrast, then the example in (27b) would also be ruled out by the constraint in (12b). We will not explore to what extent this is true. 
(28) Who ate the pasta at the party yesterday?

Hmm, pasta-wa doo-ka sira-nai-kedo,

'Well, I don't know about the pasta, but...'

a.\#BILL-GA $\underline{\underline{\text { mame-wa }}}$ 8-zi-goro tabeteita (yo)

Bill-NOM beans-WA 8 o'clock-around eating (PRT)

b. Mame $_{i}$-wa BILL-GA 8-zi-goro $t_{\mathrm{i}}$ tabeteita (yo)

beans-WA Bill-NOM 8 o'clock-around eating (PRT)

'As for the beans, Bill was eating them around 8 o'clock.'

Thus, contrary to what is commonly assumed, wa-phrases that meet the interpretive criteria for contrastive topichood must appear clause-initially. They cannot remain in situ.

Although the rule in (23) generalizes over aboutness topics and contrastive topics, the syntax of these two types of topics is not identical. As argued in the introduction, [contrast] licenses A'-movement (see (5)). This generalization seems to extend to Japanese: it has been argued that contrastive topics bind an A'-trace, while aboutness topics are basegenerated in a left-peripheral position and associated with an (empty) resumptive pronoun (Saito 1985 and Hoji 1985, but see Kuroda 1988 and Sakai 1994 for an opposing view). Hoji demonstrates that this distinction explains a number of differences between aboutness topics and contrastive topics, including contrasts involving weak crossover, reconstruction for binding and sensitivity to island constraints. For example, an aboutness topic can be associated with a position inside a relative clause, but a contrastive topic cannot. This allows the former to appear in a nonthematic, dislocated position in the matrix clause. Moreover, the pronoun inside the relative clause that is associated with an aboutness topic can be overtly realized, but positions associated with contrastive topics cannot contain a resumptive pronoun (the data below are slightly modified from Hoji 1985: 152, 161):

(29) $\underline{\text { Sono boosi } \mathrm{i}_{\mathrm{i}} \text {-wa }}\left[{ }_{\mathrm{TP}}\right.$ John-ga ${ }_{\mathrm{NP}}\left[{ }_{\mathrm{TP}} \mathrm{e}_{\mathrm{j}} \mathrm{e}_{\mathrm{i}} /\right.$ sore $_{\mathrm{i}}$-o kabutteita]

\begin{tabular}{lll}
\hline that hat-WA & John-NOM it-ACC was.wearing \\
hito $\left._{\mathrm{j}}\right]-\mathrm{O}$ & yoku sitteiru] \\
person-ACC well know &
\end{tabular}

'As for that hat, John knows well the person who was wearing it.'

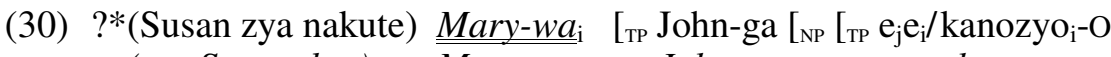
(not Susan, but) Mary-WA John-NOM she-ACC 
butta] hito $\mathrm{j}_{\mathrm{j}}$-o sagasite-iru]

hit person-ACC looking.for

Lit.:'(Not Susan, but) Mary, John is looking for a person who hit (her).'

In sum, contrastive topics in Japanese, like their Dutch counterparts, undergo A'-movement. Let us point out (perhaps superfluously) that the trigger for the movement is different in the two languages. The variation in landing site found in Dutch suggest that A'-scrambling marks the domain of contrast. The fact that topics must move to clause-initial position in Japanese is suggestive of a different trigger, possibly the marking of comments. We will not elaborate on this here, leaving (23) as a descriptive generalization.

As pointed out at the outset of this section, the rule in (23) mentions the notion [topic], rather than the morphological marker wa (which typically accompanies topics). This implies that if there are any wa-phrases not interpreted as topic, these need not appear in first position. The literature acknowledges that there are wa-phrases that need not be fronted, but at the same time it is often claimed that any constituent marked by wa is a topic (but see Kuroda 1988, 2005). However, as a matter of logic, the fact that topics are marked by $w a$ does not warrant the conclusion that $w a$ attaches only to topics. To elucidate the issue, let us consider the interpretation of non-clause-initial wa-phrases. If these systematically fail to be interpreted as topics, the rule in (23) would receive support. If they do meet tests for topichood, this would refute (23). (Rest assured: the data confirm the rule in (23)).

We first turn to unstressed wa-phrases. Although aboutness topics must appear in clause-initial position, an unstressed wa-phrase can follow a fronted focus in the response to a question like (31). The rule in (23) predicts that the wa-phrase in (31b) should not be a topic. This seems to be correct; in particular sono inu-wa 'this dog-wa' is best characterized as a simple discourse-anaphoric expression (on a par with the English pronoun in (3b)).

(31) Who did the dog bite?
a.sono inu-wa JOHN-O
that dog-WA John-ACC ye
b.JOHN $\mathrm{N}^{-} \mathrm{O}$ sono inu-wa kinoo $t_{\mathrm{i}}$ kande-simatta.
John-ACC that dog-WA yesterday bite-closed
'The dog bit John yesterday.' 
Whereas the requests in (25) and (26) require that a new unit of discourse be opened, a WH-question and the utterance that answers it belong to the same unit of discouse. Therefore, no new topic of discourse needs to be established following the question in (31). ${ }^{15}$ This allows the topic of discourse (as previously introduced) to carry over to the reply, which in turn allows 'the dog' to be a simple referring expression, rather than a linguistic topic.

That discourse anaphoricity - rather than linguistic topichood - is the relevant notion for wa-marking of the subject in the above examples is confirmed by the fact that the reply in (31b) is infelicitous if uttered in response to a question that does not mention 'the dog', such as What happened? (Kuno 1973, Tomioka 2007). ${ }^{16}$

Moreover, the $w a$-phrases in (31) do not show the syntactic behavior of topics. Recall that an aboutness topic can be base-generated in a nonthematic position in the matrix clause and be associated with an (empty) pronoun inside a relative clause. However, as shown below, an unstressed wa-phrase licensed in a context like (31) does not display such behavior, regardless of its position:

(32) Who did the dog that the child bought yesterday bite?

a. \#sono kodomo - -wa kooen-de $\left[_{\mathrm{NP}}{ }_{\mathrm{TP}} \operatorname{pro}_{\mathrm{i}} e_{\mathrm{j}}\right.$ kinoo

that child-WA park-at yesterday

15 The question in (31) establishes 'the dog' as a discourse topic if uttered discourse-initially. In this case, 'the dog' must appear in clause-initial position in the question, as in (i), indicating its linguistic topical status. On the other hand, if there is prior discourse, in which 'the dog' is already established as topic, it need not occupy clause-initial position, as in (ii).

(i) sono inu-wa dare-o kande-simatta no?

that dog-wa who-acc bite-closed $Q$

(ii) dare $\mathrm{i}_{\mathrm{i}} \mathrm{o}$ sono inu-wa $\mathrm{t}_{\mathrm{i}}$ kande-simatta no? who-acc that dog-wa bite-closed $Q$

${ }^{16}$ The claim that an in-situ unstressed wa-phrase is discourse anaphoric, and not a topic is illustrated here with subjects. The same observation holds for objects:

(i) Q: Did John borrow the book from the library?

A: Iya, John-wa sono hon-wa kekkyoku honya-de katta

No, John-wa that book-wa in.the.end bookshop-at bought 


$$
\begin{aligned}
& \text { katta] inu j]-ga } J O H N-O \quad \text { kande-simatta. } \\
& \text { bought dog-NOM John-ACC bite-closed } \\
& \text { b. \#JOHN } k_{k}-O \text { sono kodomo }{ }^{-} \text {-wa kooen-de }\left[{ } _ { \mathrm { NP } } \left[_{\mathrm{TP}} \operatorname{pro}_{\mathrm{i}} e_{\mathrm{j}}\right.\right. \text { kinoo } \\
& \text { John-ACC that child-WA park-at yesterday } \\
& \text { katta] } \text { inu }_{\mathrm{j}} \text {-ga } t_{\mathrm{k}} \text { kande-simatta. } \\
& \text { bought dog-NOM bite-closed } \\
& \text { 'The dog that this child bought yesterday bit John in the park.' }
\end{aligned}
$$

If all unstressed wa-phrases were aboutness topics, the above examples should be grammatical, on a par with the example in (29). Thus, discourse anaphoric wa-phrases have a syntax that differs from that of aboutness topics: only the latter are base-generated in a dislocated position, binding an empty pronominal in a thematic position.

We now turn to stressed wa-phrases that remain in situ, of which an example is given in (33) (see Kuno 1973, Hoji 1985, Saito 1985, Watanabe 2003 and Tomioka 2007 for discussion). It is often assumed that such $w a-$ phrases are contrastive topics. We believe that such a characterization is incorrect. Stressed in-situ wa-phrases do implicate contrast, but they fail to meet independently established criteria for topichood.

(33) Who was being helpful at the accident scene?

JOHN-GA 3-nin-wa tasuketa.

John-NOM 3-CL-WA helped

'John helped at least three people.'

There has been much recent work on the interpretation of contrastive $w a$ phrases. Hara (2006), for instance, argues that a sentence containing a stressed wa-phrase induces the presupposition that a scalar alternative stronger than the assertion exists, as well as the implicature that this stronger alternative could be false. This seems to provide a correct characterization of the interpretation of stressed $w a$-phrases, as suggested by the use of 'at least' in the English translation of (33). However, nothing in Hara's description of the semantics of contrastive wa-phrases forces these constituents to be topics. As Hara notes, stressed wa-phrases differ from contrastive topics in that they do not require the presence of a focus in the sentence, something that contrastive topics strongly favor. Moreover, it is a well-known property of topics (both contrastive and non-contrastive) that they must be specific, simply because it is difficult to make a statement about something unspecific (see Reinhart 1981). This effectively rules out a topic interpretation for 3-nin '3-classifier' in (33), which is a non-specific, quantified nominal. Indeed, an English translation of (33) that explicitly 
marks the object as a topic is decidedly odd: \#As for at least three people, John helped them.

Finally, a theory that treats all contrastive wa-phrases as contrastive topics would have to say that fronting of topics is optional. However, the wa-phrase in (34) (which, to repeat the point, does not meet the semantic criteria for topichood) resists fronting:

$$
\begin{gathered}
\# 3-\text { nin }_{\mathrm{i}} \text {-wa John-ga } t_{\mathrm{i}} \text { tasuketa } \\
\text { 3-CL-WA John-NOM helped } \\
\text { 'John helped at least three people.' }
\end{gathered}
$$

Summarizing this section, the syntactic distribution of both aboutness topics and contrastive topics in Japanese can be captured by a single rule that refers to the notion [topic]. This correctly predicts the non-topical properties of $w a$-phrases that do not occupy the clause-initial position.

\section{The position of Russian foci ${ }^{17}$}

In the previous sections we have discussed rules that mention [contrast] (Dutch A'-scrambling) and [topic] (Japanese topic fronting). We now consider a rule that mentions the third and final feature in (1), namely [focus]. The Russian data discussed below show that all foci in this language share an underlying clause-final position. In other words, the grammar of Russian has the following rule:

(35) [Focus] is licensed in clause-final position.

It is irrelevant to the argument we present whether foci are base-generated clause-finally or end up there via a derivation involving movement.

The generalization in (35) does not hold on the surface. New information foci indeed show up clause-finally, as illustrated in $(36)^{18}$, but

\footnotetext{
${ }^{17}$ This section is based on Neeleman and Titov 2008.

${ }^{18}$ The most neutral word order dictated by the context in (36) requires sentencefinal focus (see also Krylova and Khavronina 1988). However, it is possible for the focused constituent to scramble to a preverbal position in a context that does not force contrastive interpretation on the focused constituent in case this constituent is interpreted emphatically. Such constructions do not require the presence of an explicit member of the set of alternatives in the context and can often be uttered out of the blue. The emphatically focused constituent, however, cannot be analyzed as new information focus, as it contains an additional interpretation, namely a conventional scalar implicature indicating that it is surprising or noteworthy in some way (see also Zanuttini and Portner 1999 for a similar analysis of
} 
contrastive foci typically occupy positions further to the left, as we will see below (see Krylova and Khavronina 1988, King 1995, and Brun 2001).
(36) a. Čto Saša čitajet? what-ACC Sasha reads? 'What does Sasha read?'
b. Kto čitajet knigu? who reads book-ACC 'Who reads the book?'
Saša čitajet KNIGU
Sasha reads book-ACC
'Sasha reads a book.'
Knigu čitajet SAŠA book-ACCreads Sasha 'Sasha reads the book.'
c. Komu Anja dala knigu? who-DATAnna gave book-ACC Anja dala knigu KATE Anna gave book-ACC Kate-DAT 'Who did Anna give the book to?' 'Anna gave the book to Kate.'
d. Čto Anja dala Kate? Anja dala Kate KNIGU What-ACCAnna gave Kate-DAT Anna gave Kate-DATbook-ACC 'What did Anna give Kate?'
'Anna gave Kate the book.'

What our claim amounts to, then, is that the launching site for the movement of contrastive foci is the position in which new information foci must surface. This follows if contrastive foci are a composite of the features [focus] and [contrast], while new information foci are characterized by the first feature only. Movement of contrastive foci to the left periphery would then be triggered by the feature [contrast], but the launching site of that movement would be dictated by (35):

(37) a. [CP ... [FOCUS] ]
b. $\left[\mathrm{CP}[\text { FOCUS, CONTRAST }]_{1} \ldots t_{1}\right]$

The reader may wonder how we can substantiate the generalization in (35), if contrastive foci move.

exclamatives). In other words, although no explicit member of the set of alternatives is present in the context, the existence of such a set must be concluded and the emphatically focused constituent is interpreted as an unlikely member within this set:
(i). Kto čitajet knigu? who reads book-ACC 'Who reads the book?'

\author{
SAŠA čitajet knigu \\ Sasha reads book-ACC \\ '(Out of all people) it is Sasha who \\ reads the book!'
}


A first argument is that it correctly follows from (35) that new information and contrastive foci are in complementary distribution: any sentence can contain only a single focus because all foci are licensed in clause-final position. For example, a locational PP like 'in the concert hall' can appear in final position on the condition that it is interpreted as new information focus (see (38a)). This is no longer possible when another category is fronted as a contrastive focus. At best, the PP in (38b) has the status of an afterthought.

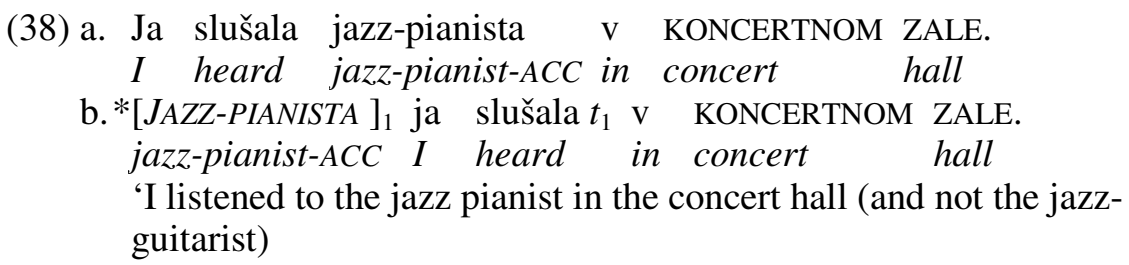

Our second argument is based on the scopal properties of contrastive foci, and in particular on the observation that they take scope in the same position as new information foci. The data fall out from (35), assuming that focus movement obligatorily reconstructs for scope. ${ }^{19}$

As a point of departure, consider the scopal properties of new information foci. In general, Russian exhibits surface scope (see Ionin 2001) and, in line with this, quantifiers that constitute a new information focus scope under other quantifiers. After all, new information foci occupy the clause-final position. ${ }^{20}$

${ }^{19}$ It has been claimed in linguistic literature that $A^{\prime}$-fronting fixes scope relations in Russian (see, for example, Bailyn 2004). However, a careful examination of Russian sentences involving A'-scrambling reveals that a longdistance scrambled DP always reconstructs into the embedded clause:

(i) Každuju devočku odin mal'čik xočet čtoby ja poljubil every girl-ACC one boy-NOM wants that I-nom loved 'One boy wants me to love every girl.' $\quad \exists>\forall ; * \forall>\exists$

The reason A'-fronting sometimes appears to result in 'frozen' scope (see (Ionin 2001) lies in the fact that a fronted quantifier not interpreted as a focus may have to reconstruct above the clause-final position, in case this position is occupied by a constituent interpreted as new information focus. This implies that the fronted quantifier must take scope over a quantified new information focus, even though it may take scope below quantifiers in other positions.

${ }^{20}$ The examples in (39a) and (39b) do not form a minimal pair. This is because there is a tendency for clause-initial objects to be interpreted as topics, and hence 
(39) a. Odin mal'čik ljubit KAŽDUJU DEVOČKU.

one boy-NOM loves every girl-ACC

'One boy loves every girl.' $\quad \exists>\forall ; * \forall>\exists$

b. V každom klasse odnu devočku ljubit KAŽDYJ MAL'ČIK. in every classroom one girl-ACC loves every boy-NOM

'In every classroom every boy loves one girl.' $\quad \exists>\forall_{\mathrm{s}} ; * \forall_{\mathrm{s}}>\exists$

c. Ty predstavil odnogo učitelja KAŽDOMU STUDENTU. you-NOM introduced one teacher-ACC every student-DAT

'You introduced one teacher to every student.' $\quad \exists>\forall ; * \forall>\exists$

d. Ty predstavil odnomu studentu KAŽDOGO UČITELJA. you-NOM introduced one student-DAT every teacher-ACC 'You introduced every teacher to one student.' $\quad \exists>\forall ; * \forall>\exists$

The pattern of surface scope breaks down in the case of contrastive foci. ${ }^{21}$ Even though these are fronted, they systematically take lowest scope. That is, they reconstruct obligatorily to a position below other quantifiers. Thus, the fronted contrastive foci in (40) take scope in exactly the same position as the in situ new information foci in (39).

(40) a. KAŽDUJU DEVOČKU ja xoču čtoby odin mal'čik ljubil every girl-ACC I-nom want that one boy-NOM loved (a ne každuju babušku).

and not every grandma-ACC

'I want one boy to love every girl (and not every $\quad \exists>\forall ; * \forall>\exists$ grandma).'

b. KAŽDYJ MAL'ČIK ja xoču čtoby $\mathrm{v}$ každom klasse every boy-NOM I-NOM want that in every classroom

as specific if they are indefinites. We control for this by adding a clause initial adverb that contains a universal quantifier on which the indefinite is dependent. This blocks a specific reading of the indefinite, as desired. The scope judgment given involves the indefinite and the universal subject (indicated by a subscript ' $S$ '). We leave out the adjunct in (39a) in order to avoid the slight artificiality of too many universal quantifiers in a single sentence.

${ }^{21}$ In the Russian linguistic literature different types of focus are taken to receive different Intonational Contours (IKs). New information focus is marked by IK1 (a falling tone), whereas contrastive focus receives IK2 (emphatic stress marked by a rising tone). For discussion, see Bryzgunova 1971, 1981, Yokoyama 1986, and Krylova and Khavronina 1988. The judgments in the main text presuppose that the constituents marked as contrastive foci bear IK2, while the rest of the sentence is destressed. 
odnu devočku ljubil (a ne každyj DEDUŠKA).

one girl-ACC loved and not every grandpa-NOM

'In every class, I want every boy to love one girl $\exists>\forall ; * \forall>\exists$ (and not every grandpa).'

c. KAŽDOMU STUDENTU ja xoču čtoby ty predstavil odnogo

every student-DAT I-NOMwant that you introduced one

učitelja, (a ne každomu PROFESSORU)

teacher-ACC and not every professor-DAT

'I want that you introduce one teacher to every $\exists>\forall ; * \forall>\exists$ student (and not to every professor).'

d. KAŽDOGOUČITELJA ja xoču čtoby ty predstavil odnomu every teacher-ACC I-NOM want that you introduced one studentu, (a ne každogo dekana).

student-DAT and not every dean-ACC

'I want that you introduce every teacher to one $\exists>\forall ; * \forall>\exists$ student (and not every dean).'

It is not very surprising that Russian contrastive foci can move, given that contrast licenses A'-movement (see (5)). However, what is surprising is that the position into which contrastive foci reconstruct should be as low as it seems to be. For example, subjects and indirect objects normally outscope direct objects in Russian, because their position c-commands (and precedes) the direct object position. However, if these elements are fronted as contrastive foci, they must scope under the direct object, suggesting that the fronting operation is launched from the sentence-final position.

A reviewer casts some doubt on the relevance of the example in (39b) in view of the preverbal position of the object, plausibly the result of a scrambling operation across the position from which the subject has moved. As a consequence, the fact that the object outscopes the subject may seem unsurprising. Three remarks are in order. First, this criticism does not extend to the data in $(39 \mathrm{c}, \mathrm{d})$. Second, the preverbal position of the object is the result of it belonging to the background. Now, backgrounded objects of monotransitive verbs may marginally be placed in postverbal position. This, however, does not affect the scopal interpretation of (39b). Third, a backgrounded object of a ditransitive verb need not be fronted if the other object appears as a sentence-initial topic (for reasons unclear to us). In this situation, a displaced contrastively focused subject must still scope under the postverbal object:

(41) Knigu [ $\left.K A \check{D} D Y J M A L^{\prime} \check{C} I K\right]_{1}$, ja xoču, čtoby dal dvum book-ACC every boy-NOM I want that gave two devočkam $t_{1}$ (a ne kažyj deduška). 
girls-DAT (and not every grandpa-NOM)

'As for books, I want every boy to give them to $2>\forall ; * \forall>2$ two girls.'

A final argument in support of (35) can be based on so-called split scrambling. Russian allows extraction of a contrastively focused element out of a larger constituent. There are many questions surrounding this phenomenon, but what is crucial here is that the material stranded by scrambling of the focused constituent provides an overt indication of the movement's launching site. If (35) holds, what we predict is that the stranded material must always occupy a clause-final position. The data below bear this out. If extraction takes place out of the object, then the object itself must be clause-final. If it takes place out of the subject, it is this constituent that must appear in clause-final position. (Although not illustrated here, other examples in which 'performance' is not clause-final are ungrammatical as well.) $)^{22}$

(42) a. JAZZ-PIANISTA mal'čiki slyshali [ vystuplenije $t$ ] jazz pianist-GEN boys-NOM heard performance-ACC

(a ne jazz-gitarista)

(and not jazz-guitarist-GEN)

'The boys listened to the performance of the jazz pianist and not of the jazz guitarist.'

b. *JAZZ-PIANISTA mal'čiki [ vystuplenije $t$ ] slyshali jazzpianist-GEN boys-NOM performance-ACC heard

(a ne jazz-gitarista)

(and not jazz-guitarist-gen)

(43) a. JAZZ-PIANISTA devočku potrjaslo [vystuplenije $t$ ]

jazz pianist-GEN girl-ACC amazed performance-NOM

(a ne jazz-gitarista)

(and not jazz-guitarist-GEN)

'The performance of the jazz pianist amazed the girl (and not of the jazz guitarist .'

b. *JAZZ-PIANISTA devočku [ vystuplenije $t$ ] potrjaslo jazz pianist-GEN girl-ACC performance-NOM amazed (a ne jazz-gitarista)

(and not jazz-guitarist-GEN)

${ }^{22}$ In (42) and (43) the DP out of which split-scrambling takes place must be sentence-final and cannot be followed by any material including adverbs. An adverb can only be added as an afterthought after a fairly long pause. 
The same point can be made on the basis of double object constructions. Split scrambling requires that the object containing the trace of the fronted constituent appear in final position:

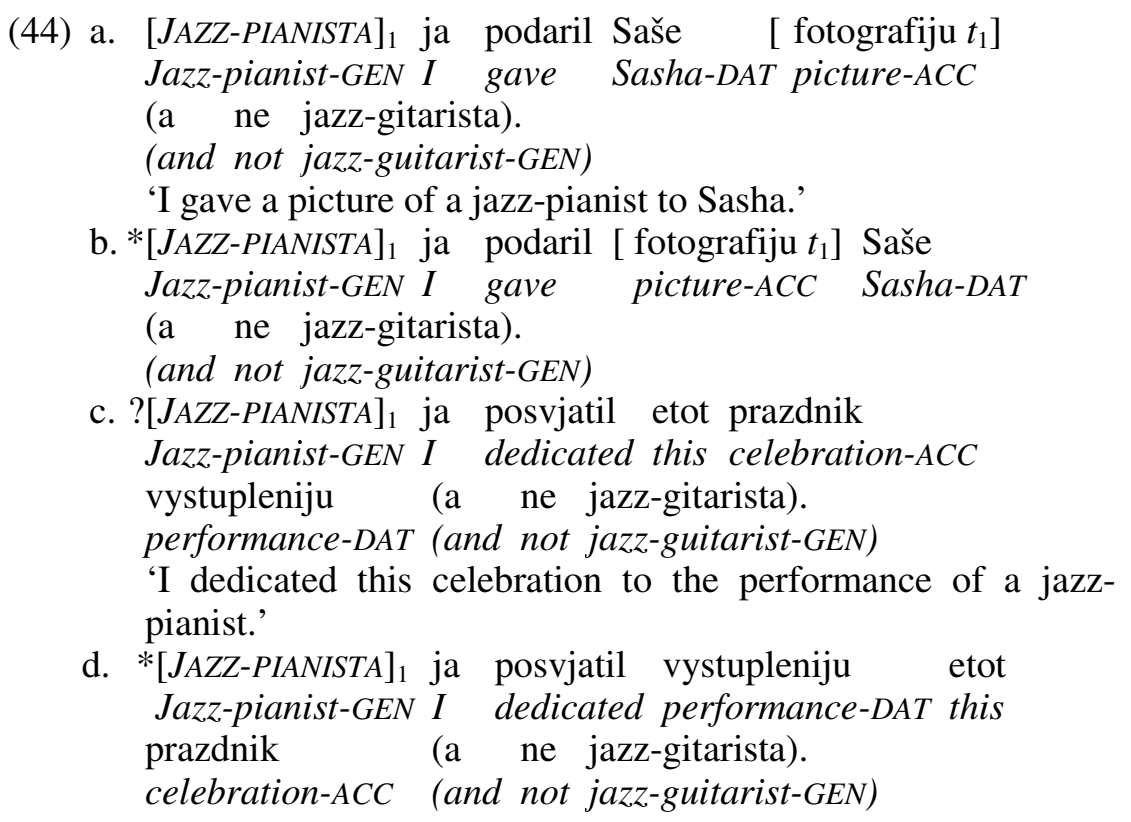

To summarize, if we assume, as stated in (35), that all foci in Russian are licensed in clause-final position, then both the scopal properties of fronted foci and the position of stranded material can be readily understood.

\section{Decomposition and cartography}

The analytical depth of our analyses of Dutch, Japanese and Russian is not equal (only in the Dutch case do we have an explanation for the empirical generalization we argued for). Nevertheless, we may draw the following conclusions: (i) There is no designated landing site for moved topics and foci (based on the Dutch data); (ii) The features [topic], [focus] and [contrast] have independent syntactic effects (based on the Dutch, Japanese and Russian data). These conclusions allow us to complete our case against cartography.

We have already argued that the variation in the landing site of A'scrambling observed in Dutch is very hard to reconcile with the rigid phrase structure that characterizes cartography. We sketched the core of the 
argument in section 4, but we can be more precise. In earlier work we have demonstrated that the following assumptions must be made if moved topics and foci are licensed in the specifier of TopP and FocP, respectively (see Neeleman and Van de Koot 2008 for details):

i. The position of TopP and FocP is free (at least in Dutch). (This captures the observed variation in landing sites.)

ii. Projection of either [contrast] or [topic] and [focus] is optional (at least in Dutch). (This allows in-situ topics and foci.)

iii. Heads containing [contrast] mark their complements as the domain of contrast. (This, in conjunction with restrictions on information structure, captures the observed ordering restrictions.)

However, each of these assumptions sacrifices an assumption central to the cartographic framework. Assumptions (ii) and (iii) give up the idea that there is a fixed clausal skeleton. Assumption (iv) gives up the idea that movement is triggered by properties of the specifier. These sacrifices seem considerable.

But the Dutch data are even more damaging in the light our second conclusion. Within the cartographic framework, the independent syntactic effects of [topic], [focus] and [contrast] require an account in terms of three separate functional projections: TopP, FocP and ContrastP. This is because cartography strives for a one-to-one relation between syntactic position and interpretive effect, and the data motivate three separate interpretively relevant syntactic features. Cross-linguistic variation would be captured by the extent to which these projections trigger displacement. In Japanese, topics appear in the specifier of TopP. In Russian, foci appear in the specifier of FocP, while contrastive foci move on to the specifier of ContrastP. Finally, in Dutch, contrastive topics and foci move to the specifier of ContrastP.

The addition of ContrastP to the topic-focus hierarchy requires an additional ordering statement. Given that TopP is generally assumed to dominate FocP, there are three logical possibilities:

(45) a. ContrastP $>$ TopP $>$ FocP

b. TopP $>$ ContrastP $>$ FocP

c. TopP $>$ FocP $>$ ContrastP

The Russian data suggest that ContrastP dominates FocP, because contrastive foci in this language move from the position in which foci in general are licensed. This rules out (45c). We are thus left with (45a) and 
(45b), but it can be demonstrated that neither of these orders is compatible with the Dutch data.

If ContrastP dominates TopP, the landing site for contrastive topics and foci is identical and it is therefore impossible to capture the ordering restrictions associated with topic and focus movement. This rules out (45a).

If ContrastP occupies a position between TopP and FocusP, one might attempt to capture the Dutch data by saying that contrastive topics move on to the specifier of TopP, while contrastive foci surface in ContrastP. We should then require TopP to trigger movement, which in turn would lead to expect displacement of aboutness topics, contrary to fact. This rules out (45b).

These considerations suggest that, although [contrast] has syntactic effects that can be distinguished from those of [topic] and [focus], a cartographic decomposition into three separate functional projections is not possible. But the logic of cartography requires such a decomposition.

\section{References}

Bailyn, John

2004. Generalized Inversion. Natural Language and Linguistic Theory 22: 1-49.

Belletti, Adriana (ed.)

2004 Structures and Beyond: The Cartography of Syntactic Structures. Vol. 3. Oxford: OUP.

Bobaljik, Jonathan

1999 Adverbs: The hierarchy paradox. Glot International 4.9/10.

Browning, Margaret

1996 CP recursion and that-t effects. Linguistic Inquiry 27: 237-256.

Brun, Dina

2001 Information structure and the status of NP in Russian. Theoretical Linguistics: 109-135.

Bryzgunova, Elena

1971 O smyslorazličitel'nyx vozmožnostjax russkoj intonatcii. Voprosy jazykoznanija 4:42-51.

1981 Zvuk i Intonatsija Russkoj Rechi. Moscow: Russkij Yasyk.

Büring, Daniel

1997 The Meaning of Topic and Focus. London: Routledge.

2003 On D-trees, beans and B-accents. Linguistics \& Philosophy 26.5: 511-545.

Choi, Hye-Won

1999 Optimizing Structure in Context: Scrambling and Information Structure. Stanford: CSLI.

Cinque, Guglielmo

1999 Adverbs and Functional Heads: A Cross-Linguistic Perspective. Oxford:

OUP.

Cinque, Guglielmo (ed.) 
2002 Functional Structure in DP and IP: The Cartography of Syntactic Structures. Oxford: OUP.

Culicover, Peter

1991 Topicalization, inversion, and complementizers in English. OTS Working Papers. Utrecht University.

Ernst, Thomas

2001 The Syntax of Adjuncts. Cambridge: CUP.

Frey, Werner

2001 About the whereabouts of indefinites. Theoretical Linguistics 27: 137-161. Giusti, Giuliana

2006 Parallels in clausal and nominal periphery. In: Mara Frascarelli (ed.), Phases of Interpretation. Berlin: Mouton de Gruyter.

Haider, Hubert

2000 Adverb placement - Convergence of structure and licensing. Theoretical Linguistics 26: 95-134.

Haider, Hubert, and Inger Rosengren

1998 Scrambling. Sprache und Pragmatik 49. Lund.

Hajičová, Eva, Barbara Partee, and Petr Sgall

1998 Focus, topic and semantics. In: Elena Benedicto, Maribel Romero, and Satoshi Tomioka (eds.), Proceedings of the Workshop on Focus. UMass WPL 21, 101-124. Amherst: GLSA.

Hara, Yurie

2006 Grammar of knowledge representation: Japanese discourse items at interfaces. Ph. D. diss., University of Delaware.

Heycock, Caroline

2007 Japanese - $w a$, $-g a$, and information structure. To appear in: Mamoru Saito, and Shigeru Miyagawa (eds.), Handbook of Japanese Linguistics. Oxford: OUP.

Hoji, Hajime

1985 Logical Form constraints and configurational structures in Japanese. $\mathrm{Ph}$. D. diss., University of Washington.

Ionin, Tania

2001 Scope in Russian: Quantifier movement and discourse function. Ms. MIT. Jackendoff, Ray

1972 Semantic Interpretation in Generative Grammar. Cambridge: MIT Press.

Jacobs, Joachim

1997 I-Topikalisierung. Linguistische Berichte 168: 91-133.

King, Tracy H.

1995 Configuring Topic and Focus in Russian. Stanford: CSLI.

Kiss, Katalin É

1998 Identificational focus versus information focus. Language 74: 245-273.

Krifka, Manfred

2006 Association with focus phrases. In: Valéria Molnár and Susanne Winkler (eds.), Architecture of Focus. Berlin: Mouton de Gruyter.

Krylova, Olga, and Serafima Khavronina

1988 Word Order in Russian. Moscow: Russky Yazyk.

Kuno, Susumu 
1973 The Structure of the Japanese Language. Cambridge: MIT Press.

Kuroda, Shigeyuki

1988 Whether we agree or not: A comparative syntax of English and Japanese. In: William J. Poser (ed.), Papers from the Second International Workshop on Japanese Syntax, 103-143. Stanford: CSLI. [Also in: Linguisticae Investigationes 12: 1-47. And reprinted in: Kuroda, Shigeyuki 1992. Japanese Syntax and Semantics: Collected Papers. Kluwer, Dordrecht.]

Kuroda, Shigeyuki

2005 Focusing on the matter of topic: A study of wa and ga in Japanese. Journal of East Asian Linguistics 14:1-58.

Lambrecht, Knud

1994 Information Structure and Sentence Form. Cambridge: CUP.

Mahajan, Anoop

1990 The A/A-bar distinction and movement theory. Ph. D. diss, MIT.

McCoy, Svetlana

2003 Connecting information structure and discourse structure through "Kontrast": The case of colloquial Russian particles -to, že, and ved'. Journal of Logic, Language and Information 12: 319-335.

Molnár, Valéria

2002 Contrast - from a contrastive perspective. In: H. Hallelgard, Stig Johansson, Bergljot Behrens, and Cathrine Fabricius-Hansen (eds.), Information Structure in a Cross-Linguistic Perspective, 147-161. Amsterdam/New York: Rodopi.

Neeleman, Ad

1994 Complex predicates. Ph. D. diss., Utrecht University.

Neeleman, Ad and Tanya Reinhart

1998 Scrambling and the PF interface. In: Miriam Butt and Wilhelm Gueder (eds.), The Projection of Arguments, 309-353. Stanford: CSLI.

Neeleman, Ad and Elena Titov

2008 Focus, Contrast and Stress in Russian. Ms. UCL.

Neeleman, Ad and Hans van de Koot

2008 Dutch scrambling and the nature of discourse templates. Journal of Comparative Germanic Linguistics 11.

Nilsen, Øystein

2003 Eliminating positions: Syntax and semantics of sentential modification.

$\mathrm{Ph}$. D. diss., Utrecht University.

Prince, Ellen

1981 Topicalization, focus-movement and Yiddish-movement: A pragmatic differentiation. Proceedings of the Berkeley Linguistic Society 7: 249-264.

Reinhart, Tanya

1981 Pragmatics and Linguistics: An analysis of sentence topics. Philosophica 27: 53-94.

1995 Interface strategies. Ms. Utrecht University.

1996 Interface economy - focus and markedness. In: Chris Wilder et al. (eds.),

The Role of Economy Principles in Linguistic Theory. Berlin: Akademic Verlag.

2006 Interface Strategies. Cambridge: MIT Press. 
Rizzi, Luigi

1997 The fine structure of the left periphery. In: Liliane Haegeman (ed.), Elements of Grammar. Dordrecht: Kluwer.

Rizzi, Luigi (ed.)

2003 The Structure of IP and CP. The Cartography of Syntactic Structures, Vol. 2. Oxford: OUP.

Roberts, Craige

1996 Information structure in discourse: Towards an integrated formal theory of pragmatics. In: James Yoon and Andreas Kathol (eds.), OSU Working Papers in Linguistics 49: Papers in Semantics, 91-136.

Rochemont, Michael

1989 Topic islands and the subjacency parameter. Canadian Journal of Linguistics 34: 145-170.

Saito, Mamuro

1985 Some asymmetries in Japanese and their theoretical implications. Ph. D. diss., MIT.

Sakai, Hiromu

1994. Complex NP constraint and case conversion in Japanese. In: Masaru Nakamura (ed.), Current Topics in English and Japanese: Proceedings of the Second English/Japanese Comparative Syntax Workshop, 179-203. Tokyo: Hituzi Syoboo.

Schwarzschild, Roger

1999 Givenness, AvoidF and other constraints on the placement of accents. Natural Language Semantics 7: 41-177.

Tomioka, Satoshi

2007a The Japanese existential possession: A case study of pragmatic disambiguation. Lingua 117: 881-902.

2007b Contrastive topics operate on speech acts. Ms. University of Delaware.

Vallduví, Enric

1992 The Informational Component. New York: Garland.

Vallduví, Enric and Elisabet Engdahl

1996 The linguistic realization of information packaging. Linguistics 34: 459-

519.

Vallduví, Enric and Maria Vilkuna

1998 On rheme and konstrast. Syntax and Semantics 29: 79-108.

Vanden Wyngaerd, Guido

1989 Object shift as an A-movement rule. MIT Working Papers in Linguistics 11: 256-271.

Van Hoof, Hanneke

2003 The rise in the rise-fall contour: Does it evoke a contrastive topic or a contrastive focus? Linguistics 41: 515-563.

Van Riemsdijk, Henk

1978 On the diagnosis of wh-movement. In: Samuel J. Keyser (ed.), Recent Transformational Studies in European Languages. Cambridge: MIT Press.

Vermeulen, Reiko

2008 \#\#\#\# 
Wagner, Michael

2005 Givenness and Locality. Ms. MIT.

Watanabe, Akira

2003 Wh and operator constructions in Japanese. Lingua 113. 519-558.

Yokoyama, Olga

1986 Discourse and Word Order. Amsterdam: John Benjamins.

Zanuttini, Rafaella and ??? Portner

1999 \#\#\#

Zwart, C. Jan-Wouter

1993 Dutch syntax: A minimalist approach. Ph. D. diss., University of Groningen. 